МОТИВАЦІЯ ТА ЇІ РОЛЬ У ПРОЦЕСІ ОСОБИСТІСНОГО РОЗВИТКУ

\title{
MOTIVATION AND ITS ROLE IN THE PROCESS OF A PERSONAL DEVELOPMENT
}

У статmі розглядається проблема мотивації як засобу розвитку особистості, не як самостійної мети, передбачає орієнтацію на внутрішню, а не зовнішню мотивацію навчання, свободу вибору людиною сфрер докладання зусиль у процесі своєї життєдіяльності. Встановлено, що особистісний аспект проблеми формування мотивації пов'язаний зі спробами утвердження власної позиції права діяти так, як хочеться, а не так, як пропонується ззовні, тому коли перед вихованцем ставиться проблема вибору, у нього породжується внутрішній конфрлікт. Узагальнено досвід науковців та практиків, які зосереджують свою увагу в основному на пізнавальному чи навчальному інтересі, залишити поза увагою інші прояви мотивації. На відміну від здібностей, мотивація є тим нестабільним внутрішнім чинником, на який потрібен вплив. Зазначено, що домінанта є мотивацією, орієнтацією, настановою, провідною потребою особи стості в реалізації їі спрямованості, будучи потужним активатором діяльності. Життєдіяльність людини є сукупністю домінант, які змінюють одна одну, які можуть бути більш-менш сильними, усвідомленими i неусвідомленими, ситуативними і довгостроковими. Узагальнено, що створення домінантної настанови-мотивації на самовиховання, формування культу самовдосконалення допоможе вирішити багато нинішніх освітніх проблем. Здобуваючи у прочесі діяльності певний досвід і якості, особистість починає на чій базі вільно і самостійно вибирати чілі та засоби діяльності, управляти своєю діяльністю, водночас удосконалювати та розвивати свої здібності до їі здійснення, змінювати та виховувати себе. З'ясовано, що становлення особистості як иілісної системи можливе лише в єдності всіх їі складових частин (інтелект, почуття, воля тощо) на певному етапі розвитку людини. Особистісний розвиток $\epsilon$ провідним у сучасному освітньому процесі.
Ключові слова: особистість, мотивація, самовдосконалення, саморозвиток, освітній процес.

The article considers with the problem of motivation as a means of personal development, not as an independent goal, provides a focus on internal rather than external motivation of learning, the freedom of choice of human spheres of effort in the process of their lives. It has been established that the personal aspect of the problem of forming motivation is related to attempts to assert one's own position of the right to act as one wants, and not as proposed from the outside, so when a pupil is faced with the problem of choice, he/she generates an internal conflict. The experience of scientists and practitioners who focus their attention mainly on cognitive or educational interest is generalized, ignoring other manifestations of motivation. As opposed to abilities, motivation is the unstable internal factor that needs to be influenced. It is noted that the dominant is the motivation, orientation, attitude, the leading need of the individual to realize its direction, being a powerful activator of activity. Human life is a set of dominants that replace each other, which can be more or less strong, conscious and unconscious, situational and long-term. It is generalized that the creation of a dominant attitude-motivation for self-education, the formation of a cult of self-improvement will help solve many current educational problems. Gaining some experience and qualities in the process of activity, the individual begins on this basis to freely and independently choose the goals and means of activity, manage their activities, while improving and developing their abilities to implement it, changing and educating themselves. It was found that the formation of personality as a whole system is possible only in the unity of all its components (intellect, feelings, liberty, etc.) at a certain stage of human development. Personal development is leading in the modern educational process.

Key words: personality, motivation, self-improvement, self-development, educational process.

Уманський державний педагогічний

університет імені Павла Тичини

Сучасний освітній процес зазнав суттєвих реформацій, об'єктивно поєднав потенціал активізації особистісного зростання, у якому створені умови для активного та спрямованого саморозвитку, що активізує та розвиває механізми самопізнання, у сенситивні періоди особистісного розвитку молодої людини.

Нині освіта задає ідеали своїм змістом для тих, хто навчається, звертає увагу на осмислення навчальних дисциплін, 3 подальшим використаннямотриманихзнаньусвоємужитті.

На основі осмислення ідеалів сучасний освітній процес зароджує розуміння морального принципу, формує цінності та переконання, які впливають на поведінку й активність, тому особистісний розвиток є провідним в освітньому процесі.

За такого підходу до освітнього процесу мотивація є засобом розвитку особистості, не як самостійна мета, передбачає орієнтацію на внутрішню, а не зовнішню мотивацію навчання, свободу вибору людиною сфер докладання зусиль у процесі професійної підготовки, своєї життєдіяльності. На думку С. Москвичова, успіх будь-яких технологій підвищення рівня навченості можливий тільки за умови адекватності мотивації та навчальної поведінки здобувачів освіти. Автор стверджує, що всі визнають важливість мотиваційного чинника у процесі опанування знань, але мало хто стверджує його вирішальне значення.

Науковці С. Москвичов, Б. Поршнєв, Г. Селевко й інші зосереджують свою увагу в основному на пізнавальному чи навчальному інтересі, залишають поза увагою інші прояви мотивації. На відміну від здібностей, вона $€$ тим нестабільним внутрішнім чинником, на який потрібен вплив. 
На думку науковців, мотивація задає тон у виявленій залежності між спонуканням і тим, що відповідає йому навчальною поведінкою. Інакше кажучи, власне психологічний аспект проблеми керівництва пізнавальною активністю здобувачів освіти багато в чому зводиться до врахування власне мотивації, або спонукальної можливості цілої низки проявів психіки [7, с. 191].

3 огляду на загальну мотиваційну значущість психічних явищ потрібно зрозуміти, яким чином їхнім наслідком виявляється готовність діяти.

Під час вивчення мотивації досить чітко виокремлюються два аспекти цієї проблематики: соціально-психологічний і особистісний. Адже, з одного боку, доводиться говорити про виховний процес, що відбувається під впливом найближчого оточення, а з іншого - не можна ігнорувати відповідну активність самого вихованця.

С. Москвичов зазнає, що успіх будь-яких технологій підвищення рівня навченості можливий тільки за умови адекватності мотивації та навчальної поведінки. Він стверджує, що всі визнають важливість мотиваційного чинника в опануванні знань, але мало хто стверджує його вирішальне значення.

Варто наголосити, що розвиток особистості піддається постійному впливу інших людей: у сім'ї, у закладах освіти, на роботі, а також із боку інших різноманітних соціальних інститутів. Усе це накладає свій відбиток на соціальну мотивацію, а потім і на поведінку, яка стає соціотипічною [2, с. 118]. Суто особистісний аспект проблеми формування мотивації пов'язаний зі спробами утвердження власної позиції права діяти так, як хочеться, а не так, як пропонується ззовні. Тому коли перед вихованцем ставиться проблема вибору, у нього породжується внутрішній конфлікт.

Б. Поршнєв характеризує розвиток особистості як історію відхилених нею альтернатив. Так чи інакше, але вибір тепер уже здійснюється суб'єктом, а не об'єктом виховного впливу. Щоб діяти, людина виходить із того, що ій властиво і сформувалося раніше. Лише на цій основі відбуваються посилення, ослаблення або відмова від цих спонукань, виникнення чогось принципово нового. У процесі розвитку в дитини формується насамперед уміння довільно встановлювати взаємозв'язок між мотивом (тим, заради чого виконується діяльність) і метою (тим, що має бути отримано в результаті діяльності). Дитина вчиться планувати, організовувати, узгоджувати свої дії, варіювати операції (способи) діяльності, заміщати їх. Вихідним положенням у цій ситуації $є$ твердження, що «свідоме управління психічним розвитком дитини відбувається насамперед шляхом керівництва <...> провідною діяльністю» [9, с. 306], якою в дошкільному віці виступає передусім гра, а в молодшому шкільному віці - навчальна діяльність.

Життєдіяльність людини є сукупністю домінант, які змінюють одна одну. Вони можуть бути більш-менш сильними, усвідомленими і неусвідомленими, ситуативними і довгостроковими.

Варто зазначити, що домінанта $є$ мотивацією, орієнтацією, настановою, провідною потребою особистості в реалізації її спрямованості, будучи потужним активатором діяльності. Домінанта - це джерело збудження в центральній нервовій системі, що діє, яке надає психічним процесам і поведінці людини спрямованість і активність у даній сфері. Вона $€$ центром, де гуртується вся діяльність, поведінка, творчість людини [14, с. 58].

Г. Селевко, який розвиває цю думку, уважає, що для того, щоб процеси самовдосконалення стали домінантними у психічному розвитку, необхідна організація таких умов, як: усвідомлення особистістю цілей, завдань і можливостей свого розвитку і саморозвитку; участь особистості в самостійній і творчій діяльності, певний досвід успіху і тренінг досягнень; адекватні стиль і методи зовнішніх дій, умов навчання і стилю життєдіяльності [13, с. 156].

Отже, створення домінантної настанови-мотивації на самовиховання, формування культу самовдосконалення допоможе вирішити багато нинішніх освітніх проблем. Особистість, яка здобуває у процесі діяльності певний досвід і якості, починає на цій базі вільно і самостійно вибирати цілі та засоби діяльності, управляти своєю діяльністю, водночас удосконалювати та розвивати свої здібності до іiї здійснення, змінювати та виховувати себе.

Основною умовою формування мети $є$ особистісний сенс тих результатів, до яких прагне людина. Досягнення мети стає сенсом їі життя.

Отже, саморозвиток людини проявляється в досягненні нею нових, якісно більш високих рівнів продуктивності як кожного психічного процесу зокрема, так і їхньої взаємодії загалом, результатом чого $€$ успішне вирішення нею все більш складних завдань. Цей саморозвиток завжди має два взаємопов'язані аспекти: звернений зовні і всередину людини. Внутрішня позиція стає тією умовою, через яку, за С. Рубінштейном, переломлюються зовнішні впливи. Чітке бачення цілей та шляхів їх здійснення, а також відповідна мотивація людини обов'язково супроводжуються адекватними їм самоконтролем і саморегулюванням роботи органів почуттів, моторики, психічного стану, самосвідомості загалом [12, с. 56].

Отже, саморозвиток $€$ багатоаспектним явищем, що відображає процес, під час якого особистість пізнає, перетворює, розвиває та вдосконалює себе. Учені розглядають його 
як цілеспрямовану різноманітну самозміну особистості, яка має на меті її максимальне духовно-етичне та діяльнісно-практичне самозбагачення та саморозкриття; самостійне її формування, спрямоване на успішну самореалізацію в суспільстві [10, с. 145].

Варто наголосити, що людина перебуває у стані саморозвитку протягом усього життя, від перших свідомих дій саморегуляції раннього дитинства до свідомої реалізації самозміни в дорослому житті. У дорослої людини цей процес може набувати різного характеру - від усвідомленого, цілеспрямованого системного позитивного самоперетворення до стагнації тасвідомоїрегресивноїзміни, саморуйнування.

Особистісний саморозвиток - це психологічний механізм «людинотворення», становлення цілісної системи, яка проявляється як корінна суперечність між наявним і необхідним рівнями психосоціальної зрілості молодої особистості.

Науковці зазначають, що саморозвиток $€$ рушійною силою розвитку на основі самопізнання, самоосмислення, актуалізує ціннісне самовизначення, служить ефективним цілепокладанням, надає енергії самовпливу у процесі будь-якої діяльності, створює смисловий простір самотворення.

Науковці В. Іванов, М. Каган, Л. Ніколов звертали увагу на системність, поліструктурність людської діяльності, а також на наявність в її структурі специфічної діяльності, пов'язаної зі зміною власного «Я» [3, с. 193].

М. Каган теоретично обґрунтував три основні її види: перетворювальну, пізнавальну та ціннісно-орієнтаційну [4, с. 53].

Вибудовуючи структури діяльності, науковець виділяє в перетворювальній сфері такий вид діяльності, у якій вона спрямовується індивідом на нього самого, на його «я», з метою фізичного або духовного самовдосконалення, у пізнавальній - самопізнання, у ціннісно-орієнтаційній - самооцінку.

Отже, саморозвиток направлено на зміну самого суб'єкта. Це внутрішня духовно-практична діяльність суб'єкта, у результаті якої змінюється його внутрішній світ.

У зв'язку із цим викликає інтерес аналіз структур індивідуальної діяльності, розпочатої болгарським дослідником Л. Ніколовим. Він виокремлює три основні її типи: перший створення умов діяльності, другий - «доставляння умов», третій - «самозадоволення проявів людських сил». Автор наголошує, що саме третій тип лежить в основі саморозвитку особистості та генезису всієї людської діяльності. Здатність людини змінювати свій внутрішній світ $€$ невіддільною від її можливості створювати нові зовнішні об'єкти. Тому якісною характеристикою людської діяльності $€$ те, що вона здатна змінювати: як внутрішнє, так і зовнішнє оточення суб'єкта, використовувати зовнішне оточення для змін у внутрішньому та навпаки [8, с. 87].

Саморозвитку будь-якої системи передують зовнішні детермінанти. Коли визначальна роль у розвитку переходить до внутрішніх детермінант, цей процес виступає як саморозвиток. Ідеться про становлення особистості як цілісної системи, яке можливе лише в єдності всіх її складників (інтелект, почуття, воля тощо) на певному етапі розвитку людини. Власне становлення особистості передбачає розвинену самосвідомість у єдності самопізнання, самооцінки, самоконтролю, саморегуляції, самоформування та самовдосконалення.

Особистість ставить перед собою мету, виявляє свою неготовність до її здійснення та починає роботу із саморозвитку. Отже, вона постійно перебуває на шляху неузгодженості між дійсним і бажаним, тому доводиться діяти та вдосконалюватися.

Долаючи цю неузгодженість, вона змушена, якщо прагне до досягнень, постійно домагатися бажаного рівня нових зусиль саморозвитку. Особистісний саморозвиток, як і шлях соціалізації людини, є значущим. Чим продуктивніше цей процес, тим більше вона розуміє себе і навколишню дійсність, нарощує здатність адаптації до неї, підвищує свою активність. Цілеспрямовано розширює водночас суб'єктний досвід діяльності та спілкування, людина набуває навички встановлення сприятливих відносин з іншими людьми, їх розуміння, а також організації діяльності, групової взаємодії тощо. Водночас проявляється діалектичний зв'язок між саморозвитком і соціалізацією людини: успішна соціалізація актуалізує цей процес, але сама вона проявляється на основі його особистісного саморозвитку [11, с. 195].

Процес формування особистості зумовлюється загальними життєвими очікуваннями та настановами. Життєві настанови залежать від того, що для неї найважливіше, отже, від мотивації, яка $є$ найбільш суттєвою в системі спонукань.

А. Маслоу встановив, що в людини є основоположні настанови, або моделі поведінки. Вона може вести себе реактивно, прагне компенсувати дефіцитну ситуацію і керується в такому разі потребами дефіциту. Або ж людина поводиться активно, хоче домогтися успіху в різних сферах життя. У цьому разі вона керується потребами розвитку. Під дефіцитом А. Маслоу розуміє ті потреби, незадоволення яких створює в організмі, так би мовити, «порожнечі», які повинні бути заповнені в ім'я збереження здоров'я організму, навіть більше, мають бути заповнені ззовні, не самим суб'єктом, а іншими людськими істотами. До них відносять стани рівноваги, гомеостазису, зняття напруги, самозахисту, інші мотивації, 
спрямовані на самозбереження. Більшість людей програмують свої вчинки і дії, звикають постійно прислухатися до своїх мотивів, пов'язаних із дефіцитом, забезпечення руху свого життя накатаною колією. Таке життя перетворює людину на звичайного респондента, «просто реагує на стимули, на заохочення та покарання, на надзвичайні обставини, на біль і страх, на вимоги інших людей, на рутинні щоденні події» [5]. Друга група мотивів, у термінології А. Маслоу, - буттєві, або «мотивація Буття», які спонукають людину підніматися над рутинним плином життя, наприклад обстоювати справедливість, боротися за істину тощо.

На думку А. Маслоу, за буттєві цінності відповідає буттєва свідомість, що поєднує в собі радість пізнання вищих цінностей. Вона взаємодіє зі звичайним, що включає оцінку, планування, ухвалення рішень.

Підвищення цілісності особистості, з одного боку, і світу, як вона його сприймає, - з іншого, опосередковують один одного.

Більш розвиненим особистостям стає доступний більш високий сенс життя.

Рушійною силою розвитку особистості, на думку А. Маслоу, є внутрішні суперечності між потребами, що постійно зростають, і можливостями їх задоволення.

Низький рівень розвитку особистості характеризується тим, що її відносини зумовлені в основному утилітарними, меркантильними інтересами. Найбільш високий рівень розвитку особистості характеризується насиченим внутрішнім світом, наявністю цінностей і розумінням сенсу життя, прагненням реалізувати свій потенціал і досягти максимально високих результатів у житті. А. Маслоу розглядав розвиток не тільки як задоволення, що прогресує, основних потреб аж до їх цілковитого зникнення, але також і як специфічну форму мотивації зростання над ними [5]. Так, розвиток талантів, здібностей, творчих нахилів, вродженого потенціалу. Одне переходить в інше і $€$ його обов'язковою умовою. Водночас психологічне життя особистості в багатьох його аспектах протікає по-різному. 3 підйомом людини в ієрархії потреб, вона стає все більш вільною у виборі напряму особистісного росту, обов'язково не просто змінюється, а розвивається як індивід, як особистість, як суб'єкт діяльності і як професіонал. Розкриття власних можливостей, потенціалу, закладенихулюдині, вимагає від неї максимальних творчих зусиль.

Особистісний саморозвиток $є$ також критерієм зрілості особистості. Зріла особистість - це людина, у якої система життєвого самовизначення духовно, морально обґрунтована, ефективна та динамічна, яка в поведінці та діяльності опирається на внутрішній локус контролю та внутрішні регулятори, усвідомлює повнотувідповідальностіза свої думки, почуття та вчинки, у якої всі інші її характеристики індивідуальна властивості, суб'єктність, індивідуальність - системно перетворені, являють собою єдність, цілісність, де, згідно із синергетичного розуміння розвитку, зміна будьякої частини зумовлює зміну всієї цілісності.

У результаті досліджень Б. Ананьєва зроблено висновок про те, що особливості великого соціуму, у якому проходить свій життевий шлях людина, неминуче накладають свій відбиток на її розвиток як індивіда, як особистості і як суб'єкта діяльності. I настільки ж сильно відбивається на ній соціальне мікросередовище, де завжди по-своєму акумулюється і переломлюється вплив великого соціуму. Однак вирішальна роль у становленні людини, у формуванні їі унікальної індивідуальності належить самій людині, її внутрішньому світу, особливо коли вона вступає в пору своєї зрілості.

Процес саморозвитку, на думку О. Бодалєва, охоплює: 1) зміни в мотиваційній сфері людини, де виражені загальнолюдські цінності; 2) зростання вміння на рівні інтелекту планувати і потім здійснювати на практиці саме ті дії і здійснювати ті вчинки, які відповідають духу названих цінностей; 3) поява більшої здатності мобілізовувати себе на подолання труднощів об'єктивного характеру; 4) більш об'єктивне оцінювання своїх сильних і слабких сторін, ступеня своєї готовності до здійснення задуманих цілей [1].

Отже, у внутрішньому світі людини постійно йдутьпроцесиформуваннятапереформування ціннісних орієнтацій, складаються та перебудовуються образи. Тут інтегруються всі її враження, узагальнюються та систематизуються індивідуальні переживання, оцінюються поведінка та вчинки. За кожною із цих змін, що означають розвиток внутрішнього світу людини, стоять якісні перебудови у психічних процесах, які лежать в основі спрямованої активності живих систем будь-яких рівнів організації.

Особистість розвивається не тільки за закладеною в ній спадковою програмою і під впливом навколишнього середовища, а й залежно від закладених у її психіці досвіду, якостей, здібностей, які формуються у процесі дорослішання і навчання.

Тому стає все більш актуальною потреба в такому освітньому впливі, який у сенситивні періоди особистісного розвитку активізує механізми самопізнання, саморегуляції та самотворення діяльності молодої людини, допоможе сприймати і поступово поглиблювати відповідний досвід життєдіяльності. 


\section{ЛІТЕРАТУРА:}

1. Бодалев А. Вершина в развитии взрослого человека: характеристики и условия достижения. Москва, 1998.

2. Вилюнас В. Психологические механизмы мотивации человека. Москва, 1990. 290 с.

3. Грень Л. Я-концепція - методологічна основа саморозвитку та самовдосконалення студентів у педагогічному процесі. Психологія і педагогіка профресійної освіти. Львів, 2008. № 3. С. 191-199.

4. Каган М. Человеческая деятельность (опыт системного анализа). Ленинград : Изд-во ЛГУ, 1992. $384 \mathrm{c}$.

5. Maslov A. Toward a psycholoqy of being. 3-nd. New York, 1968.

6. Михайличенко В. Психология развития личности : монограсрия. Харьков : НТУ «ХПИ», 2015. 388 с.

7. Москвичев С. Мотивация, деятельность и управление. Киев ; Сан-Франциско, 2003. 492 с.
8. Николов Л. Структуры человеческой деятельности. Москва, 1984. 250 с.

9. Петровский А. Психология развивающейся личности. Москва : Педагогика, 1989. 222 с.

10. Романовский О. Педагогіка успіху. Харків : НТУ «ХПИ», 2012. 370 c.

11. Романовський О., Канівець М. Сутність профе-сійно-особистісного саморозвитку майбутніх фрахівців та його механізми. Сучасні інформаційні технології та інноваційні методики навчання в підготовці срахівців : методологія, теорія, досвід, проблеми : збірник наукових праць. Київ ; Вінниця, 2013. Вип. 34. C. 193-197.

12. Рубинштейн С. Основы общей психологии : в 2-х т. Москва : Педагогика, 1989. 516 с.

13. Селевко К. Сучасні освітні технології. Київ : Народна освіта, 1999. 256 с.

14. Ухтомский А. Избранные труды. Ленинград : Наука, 1978. 358 с. 